\title{
Managing Central Asia's transboundary rivers: case studies of the Zarafshan (Tajikistan/Uzbekistan) and Tarim (Kyrgyzstan/China) rivers
}

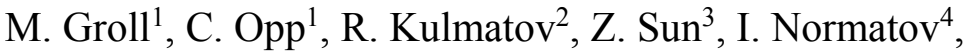 \\ A. Bernardi ${ }^{1}$, M. Ikramova ${ }^{5} \&$ G. Stulina ${ }^{6}$ \\ ${ }^{1}$ Faculty of Geography, University of Marburg, Germany \\ ${ }^{2}$ Department of Applied Ecology, \\ National University of Uzbekistan, Uzbekistan \\ ${ }^{3}$ Nanjing Institute of Geography and Limnology, \\ Chinese Academy of Sciences, China \\ ${ }^{4}$ National University of Science and Technology "MISIS", Tajikistan \\ ${ }^{5}$ Central Asian Scientific Research Institute for Irrigation SANIIRI, \\ Uzbekistan \\ ${ }^{6}$ Scientific Information Center of the Interstate Coordination Water \\ Commission of Central Asia SIC ICWC, Uzbekistan
}

\begin{abstract}
Many Central Asian river basins are transboundary and characterized by a combination of extensive irrigation farming and an arid climate in the lower catchments. Both aspects - the transboundary character with different national water management plans and the overexploitation of the limited water resources lead to environmental, socio-economic and political problems which require - in the light of growing economies and the climate change - immediate solutions. Based on extensive field work and database evaluation (meteorological, hydrological and statistical data) from the Zarafshan River (Tajikistan/Uzbekistan) and the Tarim River (Kyrgyzstan/China), the status quo of the water resources is assessed and scenarios for the impacts of climate change on the water availability and water use are outlined. The results show that the extensive withdrawal of water for irrigation farming (with cotton being the most important crop) and the
\end{abstract}


discharge of agricultural drainage water lead to severe water stress in the downstream parts of both catchments. The water deficit is so high that both rivers do not reach their tributaries (Amu-Darya and Lop Nor/Taitema Lake) any more. In the lower Zarafshan River (inter)national thresholds for several pollutants are exceeded permanently, while in the lower Tarim River the falling groundwater level is leading to the deterioration of the valuable Tugai forests. And while shortterm measures, like the water transfer from the Boston Lake to the lower Tarim, can relieve some of the pressure, the ongoing climate change and socio-economic growth in both catchments require a more integrated, sustainable management approach. The rapidly shrinking glaciers in the headwater regions $(-50 \%$ until 2050 ) and the drastic rise of the air temperature (and thus the evapotranspiration) will increase the annual water deficit (e.g. in the Zarafshan River catchment from currently $1.6 \mathrm{~km}^{3}$ to up to $5.8 \mathrm{~km}^{3}$ ), making a more efficient (re-)use of water a necessity.

Keywords: Central Asia, transboundary rivers, IWRM, irrigation, water quality, water withdrawal, climate change.

\section{Introduction}

The sustainable management of the world's limited freshwater resources is one of the most important challenges of our time. This is especially true for the vast arid regions of Central Asia. A great number of rivers in the landlocked parts of Asia are part of the vast undrained Eurasian basin, the biggest inland watershed worldwide (Opp and Groll [1]). Most of these rivers flow into terminal lakes which are characterized by natural water level fluctuations and translocations. This natural dynamic is however modified by extensive anthropogenic activities which lead to severe environmental and socio-economic problems for which the Aral Sea Syndrome is the prime but not the sole example (Opp [2]). The resources for this fragile water usage system come from the Central Asian "water towers" (Chub et al. [3]) - the highly glaciated mountain areas of the Pamir and Tien Shan mountains. The steep slopes, thin soils and low evaporation rates in the mountains lead to a rapid surface runoff, especially during the snow and glacier melt period in spring and summer, creating a good water supply in a region with overall little precipitation (Suslov [4]). This combination of abundant water supply during the vegetative period and a hot and dry climate in the lowlands is well suited for the agriculture, which has flourished in this region for many centuries (Dukhovny and de Schutter [5]). Due to the specific topography and history of Central Asia, most larger rivers also have transboundary catchments, with the mountainous upper reaches, where the runoff is generated, located in one country (Kyrgyzstan, Tajikistan or Afghanistan) and the lower reaches in the mountain foothills and the lowlands of Uzbekistan, Kazakhstan, Turkmenistan and Xinjang (China), where $90 \%$ of the water is consumed (Opp and Groll [1]). The different characteristics of the upper and lower parts of the catchments can lead to different water demands and management paradigms (UNECE [6]). The upstream countries often focus on the hydropower development with a peak water demand during the winter months, when the electricity is needed the most, while the downstream countries utilize the 
water resources mainly for their extensive export-oriented irrigation farming schemes where the water demand is highest during the summer months (Opp and Groll [1]). Due to the low irrigation efficiency, 50-80\% of the water withdrawn for agricultural needs is lost to evaporation and infiltration, which aggravates the competition for water. The results are drastic water deficits and water quality problems in the lower sections of the river catchments with severe impacts both on local water users and on the ecosystems. In the long-term, the climate change and the continuing socio-economic growth will reduce the water availability and increase the water demand (Dukhovny and de Schutter [5], Groll et al. [7]), making water-based conflicts more likely. To mitigate these conflicts between upstream and downstream water users (both on national and international levels) interstate agreements and an integrated water resource management (IWRM) have to be implemented (Abbink et al. [8]).

\section{Research areas and problem settings}

Two catchments that are exemplary for the ecological and socio-economic consequences of the current water resource management paradigm in Central Asia are the Zarafshan River and the Tarim River basins. The Zarafshan originates in the Alai Mountains in Tajikistan as the Matcha River and is later joined by the Fondarya near Aini (Fig. 1). Its current length is $810 \mathrm{~km}$ with a maximum average discharge of $155 \mathrm{~m}^{3} / \mathrm{s}$, drains a catchment of $40,600 \mathrm{~km}^{2}$ and is the lifeline for the culturally and economic important Uzbek Silk Road oases Samarkand and Bukhara (Groll et al. [7]). Until 1957 the Zarafshan reached the Amu-Darya and was its most important tributary. Since then the overexploitation of the water resources created a water deficit $\left(1.6 \mathrm{~km}^{3}\right.$ per year) so that the river currently "ends" in the Bukhara oasis. The upper catchment is characterized by the steep slopes of the Zarafshan, Turkestan and Gissar mountain ranges (all part of the Alai Mountains) which are mined for their gold, antimony, mercury, zinc, lead and coal deposits (e.g. in the Anzob ore processing complex with a capacity of 350,000 tons of ore per year, the internationally important Taror and Jilau gold mines and the Fon-Yagnob coal field which is with 1.5 bln tons the largest deposit in Central Asia). Furthermore the upper reaches have a high hydropower potential (41\% of all planned Tajik Hydropower plants are located in the Zarafshan catchment) which will (at least partially) be developed in order to reduce the countries dependency on energy imports (Haupert [9], SCIS [10]). The lower (Uzbek) parts of the catchment on the other hand are predominantly used for farming. Cotton and winter wheat are the most important crops (36\% cotton, 39\% wheat, $8 \%$ orchards, $17 \%$ other crops) grown on the 772,000 ha of irrigated land in the three provinces Samarkand, Navoi and Bukhara. Especially cotton requires large amounts of irrigation water, which is provided through a canal network of $3,140 \mathrm{~km}$ (plus additional 17,400 km of ditches). Salinization and below average soil quality require additional leaching, draining and fertilization in order to maintain the desired economic output. The agriculture in the Zarafshan River catchment is of national importance, as on $6.45 \%$ of the Uzbek territory, $18 \%$ of the irrigated land is located and $40 \%$ of all fertilizers are applied (Bucknall et al. 
[11], FAO [12]). A second impairing factor in the Uzbek part of the catchment is the industrial waste water dumped into the river (e.g. Navoiazot, located in Navoi, is the largest producer of mineral fertilizer in Uzbekistan). The combination of water withdrawal for irrigation and the inflow of pollutants from upstream mining activities as well as from agricultural drainage and industrial waste water lead to severe water quantity and quality problems in the lower reaches of the Zarafshan (Groll et al. [13]). The comparative analysis of the water quantity and quality in the Tajik and the Uzbek parts of the catchment was the main focus of this study as since the breakdown of the Soviet Union, no transboundary research had been conducted in this important catchment and the interregional data exchange is nonexistent (Chub et al. [3]).

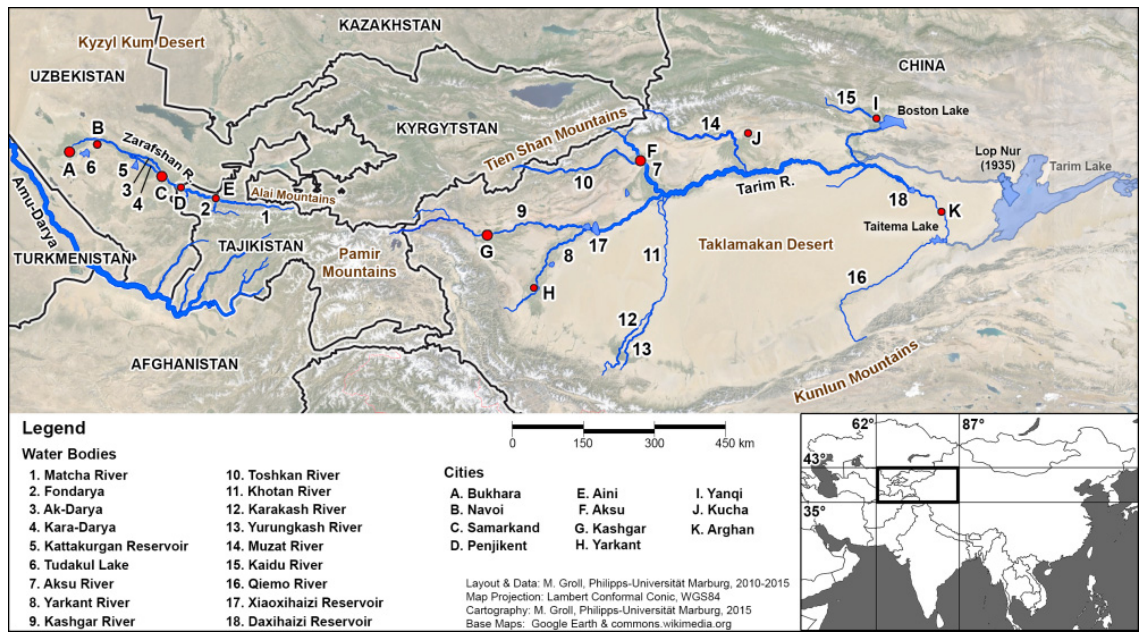

Figure 1: The Zarafshan and Tarim River catchments in Central Asia (map design: M. Groll, base map: Google Maps and commons.wikimedia.org).

The Tarim River is formed by the confluence of the Aksu River (which originates in the Kyrgyz parts of the Tien Shan) with the Yarkant (Kunlun Shan), the Kashgar (Pamir) and Khotan (Kunlun Shan) rivers (Fig. 1) and drains a catchment of $1.02 \mathrm{mln} \mathrm{km}^{2}$. Of its tributaries only the Aksu River continuously reaches the Tarim throughout the year (with an average discharge of its two tributaries Toshkan and Kumarik of $240 \mathrm{~m}^{3} / \mathrm{s}$ ) and provides between 70 and $80 \%$ of the total discharge, even though up to $60 \%$ of the Aksu water resources are consumed before it reaches the Tarim (Huang et al. [14]). With a total length of $2,030 \mathrm{~km}$ the Yarkant-Tarim river system is the longest inland river in China and the second longest inland river worldwide. Even more so than the Zarafshan River, the middle and lower reaches of the Tarim are characterized by aridity (annual precipitation $<50 \mathrm{~mm}$, potential annual evaporation $>2,000 \mathrm{~mm}$ ), as the river follows the northern border of the Taklamakan desert for approximately $500 \mathrm{~km}$. Until the 1930s the Tarim flowed into the Lop Nur terminal lake, a salty endorheic 
remnant of the post-glacial Tarim Lake which once covered more than $10,000 \mathrm{~km}^{2}$ between the Taklamakan and Kumtag deserts. Since then, the Lop Nur is completely dried up and is currently used for the large-scale mining of potassium chloride. The Taitema Lake formed a secondary terminal lake $160 \mathrm{~km}$ southwest of the Lop Nur, but extensive water consumption since the 1950s and the construction of eight large reservoirs (especially the Daxihaizi Reservoir in the lower Tarim River catchment and the Xiaoxihaizi Reservoir in the Yarkand River catchment) with a total capacity of $528 \mathrm{mln} \mathrm{m}^{3}$ has led to the desiccation of the Taitema Lake in 1974 (Xu et al. [15], Sun et al. [16], Xia [17], Ginau et al. [18]). The water is primarily used for the irrigation of the Silk Road oases of Kashgar, Khotan, Aksu and Kucha as well as for the large state farms in the Tarim basin (a total of $5,269 \mathrm{~km}^{2}$ of irrigated land annually consuming $10.83 \mathrm{~km}^{3}$ of water) (Chen et al. [19], Ginau et al. [18], Feng et al. [20]). Both the cities and the state farms are characterized by a strong population growth $(8.26 \mathrm{mln}$ in 2005) which is accelerated by the Chinese government in the form of the xibu-da-kaifa program, which promotes the inner-Chinese migration to Xinjang and other western provinces (Becquelin [21], Lai [22]). This overexploitation of the available water resources has led to a severe stress for the fragile riparian Tugai forests along $320 \mathrm{~km}$ of the lower Tarim River and the deterioration of the groundwaterdependant Populus euphratica communities (covering 459,800 ha in 1958 and 245,900 ha in 1998; Ginau et al. [18]). In recent years, revitalizing these Tugai forests and securing the water supply in the middle and lower reaches of the Tarim became a focus of the largest environmental restoration project in China (Qian [23]). Since the year 2000 water was diverted 14 times from the Boston Lake through the Kaidu River and an artificial canal into the Daxihaizi Reservoir and from there into the lower Tarim (Sun et al. [16]). The water (a total of $4.2 \mathrm{bln} \mathrm{m}^{3}$ ) flooded the dry riverbed, reaching the Taitema Lake for the first time in 30 years after 10 of the 14 floodings. Until the summer of 2001 the Taitema lake had been completely dry and after the fifth flooding (August-November 2003) its surface area had increased to $200 \mathrm{~km}^{2}$. The water influx into the lower Tarim increased the groundwater level from $8-13 \mathrm{~m}$ to $2-4 \mathrm{~m}$ and reduced the mineralization of the surface water from 3-11 g/l to $1.5-2.6 \mathrm{~g} / \mathrm{l}$. The number of plant species in the riparian zone of the lower Tarim increased from 17 to 46 and the overall vegetation coverage grew from $230 \mathrm{~km}^{2}$ to $1,000 \mathrm{~km}^{2}$ (Ginau et al. [18]). But whether and under what circumstances the Tugai forests could permanently benefit from these short-term "ecological floodings" remained unclear and thus was the focus of the study in this research area.

\section{Methods and research setup}

The findings presented here for the Zarafshan River catchment are based on own field measurements conducted in 2010, laboratory data from the Uzbek hydrometeorological service (2002-2010), glacier data from the Tajik Academy of Sciences (1927-2010), discharge and irrigation data from the SIC ICWC (Scientific Information Center of the Interstate Coordination Water Commission) 
and the SANIIRI (Central Asian Irrigation Research Institute, 2004-2006), longterm meteorological data from the RWSA (Russia's Weather Server Archive), the GHCN (Global Historical Climatology Network) and the NEESPI (Northern Eurasia Earth Science Partnership Initiative) (1891-2012), discharge data from the NEESPI and the GRDD (Global River Discharge Database) (1913-2012) as well as an extensive literature analysis. The collected data cover the status quo of the hydro-meteorological characteristics of the Zarafshan as well as relevant water quality parameters. All data was statistically analyzed and spatial and temporal dynamics were identified.

In the Tarim River catchment, two field campaigns in the lower Tarim region around Arghan (between the Daxihaizi Reservoir and the Taitema Lake) were carried out in a $10 \mathrm{~km}$ wide buffer zone around the Tarim riverbed (Sun et al. [16]). Within this zone the status quo of the Populus euphratica populations was assessed using the three parameters diameter at breast height (DBH), tree height and tree vitality (in five classes ranging from VL1 (vital tree, nearly no loss of crown, leaves mostly dark green) to VL5 (no vital branches, crown loss 100\%)). This vitality assessment was complemented by 33 detailed soil analyses in both river terrace profiles and dug profiles under different micro-relief conditions like sand covered dune hills and dune hollows. Soil features such as sediment respectively substratum layer thickness, soil horizons, color, humus content, grain size, pore size distribution and carbonates were documented in the field according to Boden [24]. All findings were also documented through photographs and scaled drawings. Identified sediment layers and soil horizons were sampled and analyzed in the laboratory using AAS (Atomic Absorption Spectroscopy), XRD (X-Ray Diffraction; Philips X'Pert MPD), $\mathrm{pH}$, electric conductivity and grain size (sieving and pipette analysis, calculation with Gravistat) methods. The mineral composition was calculated from measured XRD spectra via quantitative Rietveld refinement (Ginau et al. [18]). Additional NDVI (Normalized Difference Vegetation Index) analyses were conducted using MODIS NDVI datasets (20002007, bands 1 and 2 of the Terra satellite, Sun et al. [16]).

\section{Results}

\subsection{Zarafshan River}

The maximum long-term average discharge of the Zarafshan River is $155 \mathrm{~m}^{3} / \mathrm{s}$ at the Tajik-Uzbek border (hydropost Ravathodja). Immediately downstream of this point $61.8 \%$ of the water (up to $215 \mathrm{~m}^{3} / \mathrm{s}$ in July) is withdrawn throughout the year. Three major canals (Bulungur, Dargom and Pravoberejnyi) distribute the water into the Samarkand province and into the Kattakurgan Reservoir (capacity 900 $\mathrm{mln} \mathrm{m}^{3}$ ). Additional water diversions in the Navoi province further deplete the water resources so that the average runoff at the hydropost Khatyrchi $(200 \mathrm{~km}$ downstream of the border) is just $36.4 \mathrm{~m}^{3} / \mathrm{s}$ and another $180 \mathrm{~km}$ downstream, near Ghijduvan, the Zarafshan officially ceases to exist (Fig. 2). 


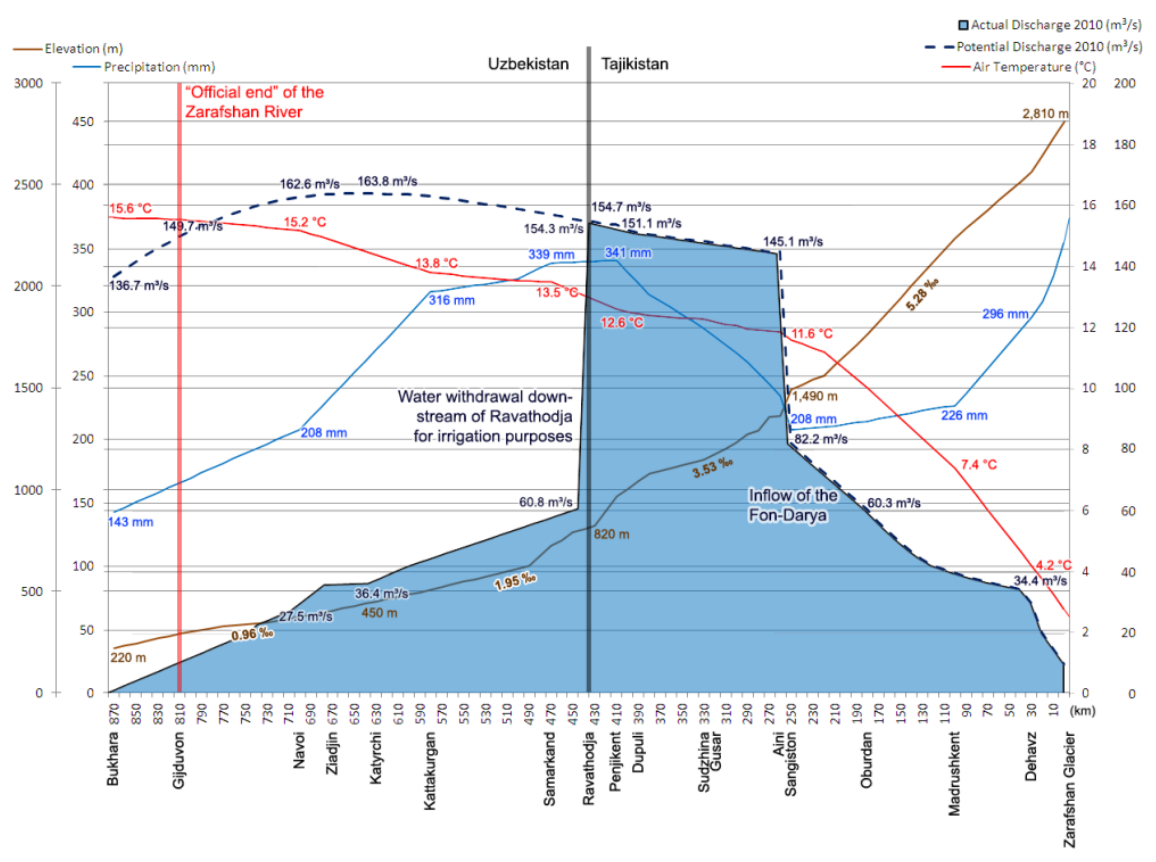

Figure 2: Basic characteristics (elevation, air temperature and precipitation), actual and potential discharge along the Zarafshan River.

All in all, 11 reservoirs with a total capacity of $2.3 \mathrm{~km}^{3}$ are used to manage and distribute the Zarafshan water resources. At the same time the input of drainage water from the irrigated fields, collected through a canal network of 3,292 km length, is increasing from the Samarkand to the Navoi province, leading to a dramatic impairment of the water quality. The mineralization, as a parameter for the overall water quality increased exponentially $\left(\mathrm{R}^{2}=0.926\right)$ between the TajikUzbek border $(243.1 \mathrm{mg} / \mathrm{l})$ and the official end of the river $(1,799.0 \mathrm{mg} / \mathrm{l})$. Both the transboundary field measurements and the long-term monitoring conducted by the UZHYDROMET showed, that the national threshold for the mineralization is exceeded downstream of Navoi, where the agricultural and the industrial waste water have a combined effect. The analysis of different water body categories identified the drainage water collectors as the main source of this pollution as the average mineralization in the sampled collectors was $2,235 \mathrm{mg} / \mathrm{l}$. A similar increase along the Zarafshan was detected for Nitrate $(4-10 \mathrm{mg} / \mathrm{l}$ at the border and up to $75 \mathrm{mg} / \mathrm{l}$ downstream of Navoi), Copper $(0.002 \mathrm{mg} / \mathrm{l}$ at the border, $2.35 \mathrm{mg} / \mathrm{l}$ downstream of Navoi), Chromate VI $(0.5 \mathrm{mg} / \mathrm{l}$ at the border, $1.5 \mathrm{mg} / \mathrm{l}$ downstream of Navoi) and Phenols ( $0 \mathrm{mg} / \mathrm{l}$ at the border, $0.01 \mathrm{mg} / \mathrm{l}$ downstream of Navoi). Phosphate also showed increased concentrations in the Uzbek part of the catchment (up to $100 \mathrm{mg} / \mathrm{l}$ ), but the highest levels of phosphate were detected in the upper Tajik catchment where erosion from the steep and hardly vegetated slopes led to concentrations of up to $250 \mathrm{mg} / \mathrm{l}$. National and international 
thresholds were exceeded for several pollutants (arsenic, copper, chromate, nitrate, phenols, and phosphate) in most parts of the Uzbek catchment. This is especially alarming as the heavily polluted drainage and waste water is returned to the river untreated or directly used for further irrigation downstream.

\subsection{Tarim River}

The ecological floodings led to a broad-scale revitalization of the riparian vegetation in the lower Tarim. The NDVI shows a significant increase between 2001 and 2007 (Fig. 3) which correlates to the ecological floodings but is independent from the precipitation dynamic (Sun et al. [16]).

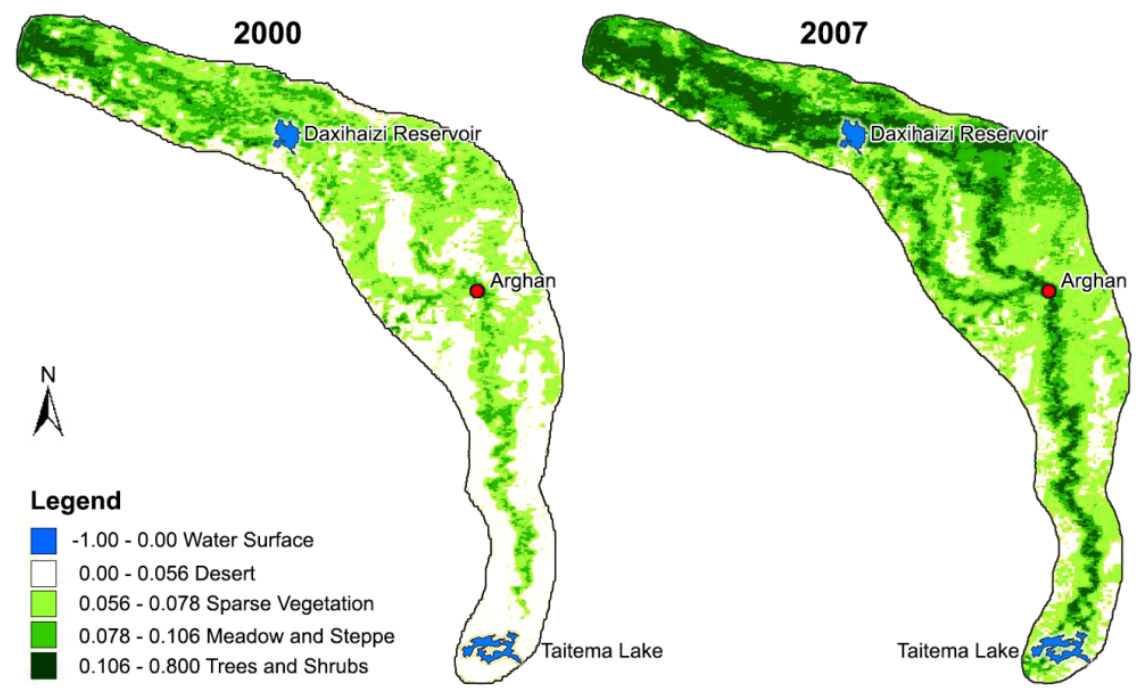

Figure 3: Vegetation cover change in the lower Tarim research between 2000 and 2007.

Interestingly the vegetation's response to the floodings occurred not immediately, but with a temporal shift of up to one year, indicating water storage in the soils. The percentage of trees and shrubs in the research area increased from $2.2 \%$ (2000) to $15.9 \%$ (2007). The field work in the research area however revealed that the onsite reaction of Popolus trees varied widely, even if both the distance to the river and the groundwater level were comparable. The temporal shift and the differentiated vegetation response emphasize the importance of the soil characteristics for the longevity of the ecological floodings. The dominant grain size in the 33 soil profiles was fine sand $(0.063-0.2 \mathrm{~mm})$ (Fig. 4A) and the humus contents were in general low (ranging between 1 and 7\%). However, higher amounts of clay (up to 38\%) and humus were detected in different depths and were related to fossil soil horizons derived from fluvial sediments. The most common sediment layers were a near-surface aeolian fine-sand pocket with an Arenosol, 
and an underlying fluvial sandy loam/fluvial silt pocket with a Fluvisol. The main sediment layers, the aeolian and fluvial layers, consisted of several sediment generations. In between the fluvial loam or fluvial silt, various micro-layers of clayey material were detected, partly combined with imbedded humic horizons. A positive correlation between deep profiles of stratified fine sandy/silty and clayey micro-layers, covered by a mighty aeolian sediment pocket with a good tree vitality (VL1/VL2) was confirmed. The mighty sandy sediment pockets function as a protection against evaporation, while at the same time being permeable enough to allow root growth.

A deep sequence of fine sandy/silty and clayey micro-layers is an ideal prerequisite for water storage and water passage (Fig. 4B). The deep clayey microlayers are well suited for retaining water and nutrients. Vital trees are a sink for sand, which forms little sandy hills around the trunks which protect the root zone against evaporation. Sample sites with just one mighty clayey layer and without intercalated sandy material on the other hand were characterized by low tree vitality classes (VL4/VL5, Fig. 4D). Here the clay acts as a strong barrier for both water and roots. Finally, shallow profiles of clayey material topped by only thin layers of sand were detected most often near the current riverbed of the Tarim (Fig. 4C). Populus seedlings in these locations initially have good growth conditions. However, as they grow older, they cannot survive the longer drought periods as they are highly dependent on sufficient surface water supply. They often die because of evaporation and/or dryness stress or because of a limited root penetration or near-surface salt accumulation.
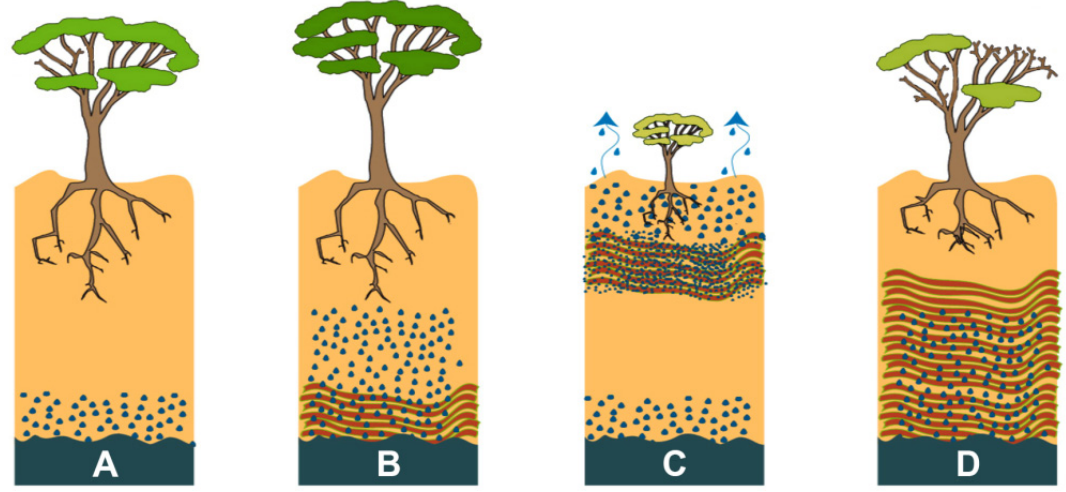

Figure 4: Soil structure types in the lower Tarim research area and their influence on water storage, water passage and tree vitality (modified after: Ginau et al. [18]).

\section{Outlook}

Both catchments are characterized by an overexploitation of the water resources for the extensive irrigation farming. And in both cases the resulting water deficit heavily impairs the lower parts of the catchments. Over the next decades this 
situation will only get worse in both catchments as the climate change and the socio-economic growth increase the pressure on the water resources. As an effect of the global warming the Central Asian glaciers are already receding at an accelerating speed $(0.026-0.5 \%$ per year during the first half of the 20th century, 0.14-1.0\% during the second half of the 20th century) (Chub et al. [3], Groll et al. [13]). By 2050 the Zarafshan glacier could be reduced to just $50 \%$ of its current size while the large number of smaller glaciers $\left(<1 \mathrm{~km}^{2}\right)$ in the catchment will be completely gone. The Tien Shan glaciers on the other hand experienced an annual recession of $0.1-0.7 \%$ during the second half of the $20^{\text {th }}$ century, resulting in a similar prognosis as for the Zarafshan glaciers (Sorg et al. [25], Aizen et al. [26]).

As both rivers are mainly fed by glacier melt water this will directly affect the runoff, which could in 2050 be up to $30 \%$ lower than in 2010 . The water demand on the other hand will equally increase over the next decades as the higher air temperatures lead to higher evapotranspiration rates and longer vegetative periods. Even more important however will be the continued socio-economic growth $(+1.7 \%$ annual population growth and $+8 \%$ annual economic growth for Uzbekistan (2010) (Groll et al. [7]), $+2.1 \%$ annual population growth and $+11.3 \%$ per capita GDP growth in in Xinjang (1995-2000) (Toops [27]). The combined increased water demand could be up to $30 \%$ higher in 2050 than in 2010 (Dukhovny and de Schutter [5], Groll et al. [7, 13]). A third factor influencing the water availability is the possible implementation of additional reservoirs and hydropower projects in the region. If or when such projects in the Zarafshan and Tarim river basins will be implemented is uncertain, but both Tajikistan and Kyrgyzstan put great emphasize on the development of their national hydropower potential. And additional irrigation water reservoirs could be necessary to stabilize the water supply in times of increased rainfall and overall reduced water availability.

The combination of reduced water availability and increased water demand could increase the annual water deficit in the Zarafshan River catchment from currently $1.6 \mathrm{~km}^{3}$ to up to $5.8 \mathrm{~km}^{3}$ (Groll et al. [7]). The lower Tarim River catchment would require additional ecological floodings in order to at least sustain the status quo of the riparian ecosystems. But with an already low water level in the Boston Lake and the expected decrease of the available water resources, the frequency of these floodings will have to be cut back - if they continue at all. Furthermore it can be expected that the water deficit in both catchments will affect the midstream sections as well, which are currently still well supplied with water. The present state of the lower catchments (high water mineralization and pollution, soil salinization, desertification) might insofar provide an outlook onto the challenges the midstream sections might face by the middle of the $21^{\text {st }}$ century.

As neither the reduced water availability nor the socio-economic growth can be influenced by the decision makers in the region in any meaningful way, the emphases for overcoming these challenges have to be placed on the development and implementation of water saving and purification techniques. Possible approaches that are still underutilized in the region are widespread waste water treatment in all sectors, the efficient reuse of drainage water and a tailored to demand use of fertilizers, drip irrigation instead of furrow irrigation, the 
cultivation of less water demanding crop alternatives, the reduction of water losses in irrigation canals and reservoirs and the economic growth in the agricultural sector through deeper value creation chains instead of expanding irrigation areas.

\section{References}

[1] Opp, Ch. \& Groll, M., Status quo and development of Central Asia's transnational rivers - case studies from the Zarafshan River and the Tarim River. Mat. of the Int. Conf. Remote- and Ground-based Earth Observations in Central Asia: Bishkek, pp. 265-271. 2014. DOI: 10.13140/ 2.1.4224.3840.

[2] Opp, Ch., Vom Aralsee zur Aralkum - Ursachen, Wirkungen und Folgen des Aralsee-Syndroms. Asien, ed. R. Glaser \& K. Kremb, pp. 90-100, 2007.

[3] Chub, V., Agaltseva, N. \& Myagkrov, S., Climate change impact on the rivers runoff for the Central Asian River. Proc. of the Int. Conf. on Hydrology and Watershed Management with the Focal Theme on Water Quality and Conservation. Vol. 2, pp. 252-257, 2002.

[4] Suslov, S.P., Physical Geography of Asiatic Russia: Moscow, 594 pp., 1961.

[5] Dukhovny, V.A. \& de Schutter, J.L.G. (eds). Water in Central Asia - Past, Present, Future. CRC Press: Leiden, 408 pp., 2011.

[6] UNECE - United Nations Economic Commission for Europe (ed.), Convention on the Protection and Use of Transboundary Watercourses and International Lakes - as amended along with decision VI/3 clarifying the accession procedure. UNECE doc MP-WAT-41, 54 pp., 2013.

[7] Groll, M., Opp, Ch., Kulmatov, R., Normatov, I., Stulina, G. \& Shermatov, N., Water resources in Central Asia - status quo and future conflicts in transboundary river catchments - the example of the Zarafshan River (Tajikistan-Uzbekistan). Proc. of the General Assembly of the EGU, 42 pp. 2014. DOI: $10.13140 / 2.1 .4005 .7128$.

[8] Abbink, K., Moller, L.C. and O'Hara, S., Sources of mistrust - an experimental case study of a Central Asian water conflict. Environmental Resource Economics, 45, pp. 283-318, 2009.

[9] Haupert, T., Economic Developments in Tajikistan. Global Tides, 2(2), 25 pp., 2008.

[10] SCIS - State Committee on Investment and State Property Management of the Republic of Tajikistan (ed.), National development strategy of the republic of Tajikistan for the period to 2015, 50 pp., 2007.

[11] Bucknall, J., Klytchnikova, I., Lampietti, J., Lundell, M., Scatasta, M. \& Thurman, M., Irrigation in Central Asia - social, economic and environmental considerations. World Bank Report, 104 pp., 2003.

[12] FAO - Food and Agricultural Organization of the United Nations (ed.) Fertilizer use by crop in Uzbekistan. 31 pp., 2003.

[13] Groll, M., Opp, Ch., Kulmatov, R., Ikramova, M. \& Normatov, I., Water quality, potential conflicts and solutions - an upstream-downstream analysis of the transnational Zarafshan River (Tajikistan, Uzbekistan). 
Environmental Earth Sciences 73, pp. 743-763, 2015. DOI: 10.1007/ s12665-013-2988-5.

[14] Huang, S., Krysanova, V., Zhai, J. \& Su, B., Impact of intensive irrigation activities on river discharge under agricultural scenarios in the semi-arid Aksu River basin, Northwest China. Water Resource Management 29, pp. 945-959, 2015. DOI: 10.1007/s11269-014-0853-2.

[15] Xu, Z., Liu, Z., Fu, G. \& Chen, Y., Trends of major hydroclimatic variables in the Tarim River basin during the past 50 years. Journal of Arid Environments 74(2), pp. 256-267, 2010. DOI: 10.1016/j.jaridenv.2009. 08.014.

[16] Sun, Z., Opp, Ch. \& Wang, R., Vegetation response to ecological water diversion in the lower Tarim River, Xinjang, China. Basic and Applied Dryland Research 3, pp. 1-16. 2009. DOI: 10.1127/badr/3/2009/1.

[17] Xia, X.C., The scientific exploration and research on the Lop Nur. Science Press, pp. 1-5, 1987.

[18] Ginau, A., Opp, Ch., Sun, Z. \& Halik, Ü., Influence of sediment, soil, and micro-relief conditions on vitality of Popolus euphratica stands in the lower Tarim Riparian Ecosystem. Quaternary International 311, pp. 146-154, 2013. DOI: 10.1016/j.quaint.2013.06.025.

[19] Chen, Y., Takeuchi, K., Xu, C., Chen, Y.\& Xu, Z., Regional climate change and its effects on river runoff in the Tarim Basin, China. Hydrological Processes 20, pp. 2207-2216, 2006. DOI: 10.1002/hyp.6200.

[20] Feng, Q., Endo, K.N. \& Cheng, G.D., Towards sustainable development of the environmentally degraded arid rivers of China - a case study from Tarim River. Environmental Geology 41, pp. 229-238, 2001. DOI: $10.1007 / \mathrm{s} 002540100387$.

[21] Becquelin, N., Staged Development in Xinjang. The China Quarterly 178, pp. 358-378, 2004. DOI: 10.101/S0305741004000219.

[22] Lai, H.H., China's Western Development Program. Modern China 28(4), pp. 432-466, 2002. DOI: 10.1177/009770002237663.

[23] Qian, Z.Y., Strategic study on allocation of water resources, conservation and upgrading of eco-environment and sustainable development in NorthWest China. Science Press 499, 2004.

[24] A.G. Boden (ed). Bodenkundliche Kartieranleitung, $5^{\text {th }}$ Edn., 438 pp., 2005.

[25] Sorg, A., Bolch, T., Stoffel, M., Solomina, O. \& Beniston, M., Climate change impacts on glaciers and runoff in Tien Shan (Central Asia). Nature Climate Change 2, pp. 725-731, 2012.

[26] Aizen, V.B., Aizen, E.M. \& Kuzmichonok, V.A., Glaciers and hydrological changes in the Tien Shan - simulation and prediction. Environmental Research Letters 2, pp. 1-10, 2007.

[27] Toops, S., Demographics and development in Xinjang after 1949. EastWest Center Working Papers 1, 29 pp., 2004. 